\title{
PRONOMINA BAHASA KADAI
}

\section{PRONOUN OF KADAI}

\author{
Noormala \\ Kantor Bahasa Maluku Utara \\ Jalan Wijaya Kusuma Nomor 81, Kota Baru, Ternate Tengah, Maluku Utara \\ Pos-el: noormala.spd@gmail.com
}

\begin{abstract}
Abstrak
Bahasa Kadai merupakan salah satu bahasa daerah yang terdapat di Maluku Utara dan dituturkan oleh etnik Kadai. Tulisan ini bertujuan mendeskripsikan pronomina bahasa Kadai. Pengumpulan data dilakukan dengan menggunakan metode simak, cakap, dan introspeksi. Data yang terkumpul dianalisis dengan pendekatan struktural dan metode distribusional dengan teknik dasar dan teknik lanjutan. Hasil penelitian menunjukkan bahwa bahasa Kadai memiliki pronomina persona, yaitu $a k u$ 'saya', io 'dia', kami 'kami', kito 'kita', kou 'kamu', ke 'engkau', dan matu 'mereka', pronomina demonstratif, yaitu yai 'ini' dan yo 'itu', dan pronomina introgatif, yaitu woi 'siapa', dan mansa 'apa'.
\end{abstract}

Kata kunci: bahasa Kadai, pronomina, metode distribusional

\section{Abstact}

Kadai is one of vernacular language found in North Maluku that spoken by Kadai etnic. This paper aims at to describe the pronoun of Kadai language. Collective data is done by using observation method, interview method, and evaluation method. Those collective data is then analyized by structural approachment and distributional method by using basic and contininou technique. The result shows that Kadai has the pronoun of noun, namely aku 'I', io 'she/he/it', kami 'we', kito 'we', kou 'you', ke 'you', dan matu 'they', demonstrative pronoun, namely yai 'this/that' and yo 'those/these', and introgative pronoun, namely woi 'who' and mansa 'what'.

Keywords: Kadai, pronoun, distributional method

\section{Pendahuluan}

Peraturan Daerah Provinsi Maluku Utara Nomor 9 Tahun 2009 tentang Pemeliharaan Bahasa dan Sastra Daerah menyebut ada 31 di Maluku Utara dan bahasa Kadai (BK) adalah salah satu bahasa daerah yang termasuk disebut di dalam perda tersebut. BK dituturkan oleh etnik Kadai dan wilayah penyebarannya ditemukan di Desa Samuya, Kecamatan Taliabu Timur, Pulau Taliabu.

Di desa Samuya, tercatat ada 354 orang Kadai dari 1134 orang dengan latar belakang etnik yang berbeda, yakni etnik Sula, Buton, Bugis, Flores, Minahasa, dan Jawa. Secara geografis, desa Samuya yang berada di
Kecamatan Taliabu Timur terletak di antara $1^{0} 40^{\prime}-2^{0} 00^{\prime}$ Lintang Selatan dan $124^{0} 52^{\prime}-$ $125^{\circ} 20^{\prime}$ Bujur Timur. Sebelah utara Kecamatan Taliabu Timur sebelah Utara berbatasan dengan Laut Maluku, sebelah selatan berbatasan dengan Kecamatan Taliabu Timur Selatan, sebelah timur berbatasan dengan Selat Capalulu, dan sebelah barat berbatasan dengan Kecamatan Taliabu Utara. Kecamatan Taliabu Timur merupakan daerah pesisir dengan ketinggian 0-4 meter di atas permukaan laut (BPS Kabupaten Kepulauan Sula, 2016). Desa Samuya adalah desa yang paling luas daratannya, yakni $325,79 \mathrm{~km} 2$. Berikut peta Pulau

Taliabu: 


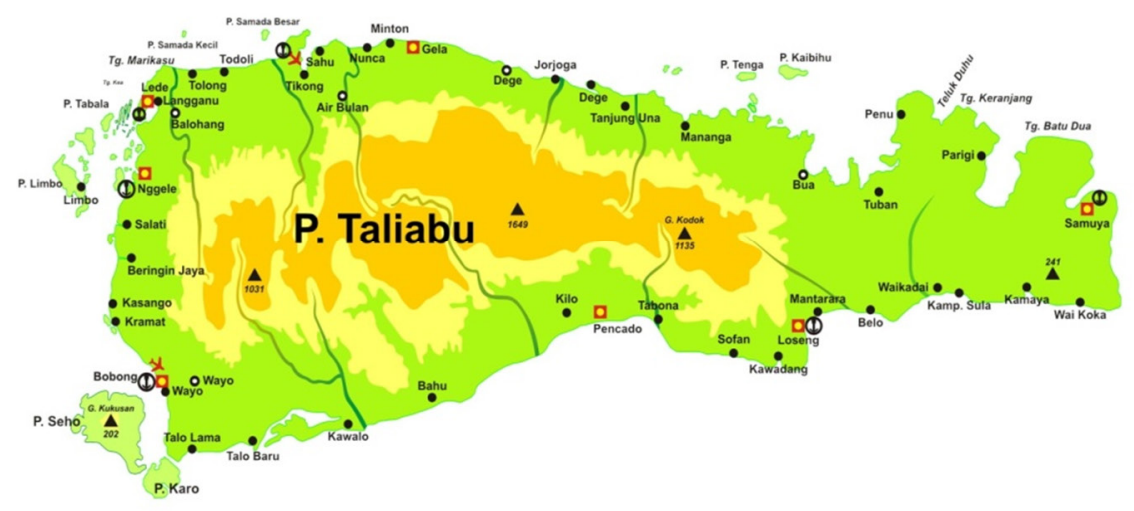

Gambar: Pulau Taliabu

Kata Kadai berasal dari Kadahi yang berarti 'kami dapat'. Namun, seiring perkembangan zaman, kata tersebut mengalami pelesapan menjadi kadai. Masyarakat Kadai umumnya mendiami pesisir pantai. Mereka membuat rumah dengan menggunakan kayu yang beratapkan daun woka, sejenis daun kering sebagai tempat berlindung. Dalam memenuhi kebutuhannya, mereka tidak hanya menangkap ikan, melainkan bertani dengan menanam jagung, ubi, dan kelapa.

Pada tahun 2015, tim peneliti Kantor Bahasa Maluku Utara telah melakukan penelitian fonologi BK. Hasil penelitian tersebut menyebutkan bahwa pada BK terdapat lima vokal, yakni [a], [i], [u], [e], [o], tujuh belas konsonan, yakni $[\mathrm{b}],[\mathrm{c}],[\mathrm{d}],[\mathrm{f}],[\mathrm{g}],[\mathrm{h}]$, $[\mathrm{j}],[\mathrm{k}],[1],[\mathrm{m}],[\mathrm{n}],[\mathrm{p}],[\mathrm{r}],[\mathrm{s}],[\mathrm{t}],[\mathrm{w}],[\mathrm{y}]$, dua macam diftong yang terdiri atas diftong naik ([ai], [au], [oi], [ou], [ae], [ao], [eu], [ei]) dan diftong turun ([ou], [ua], [ue], [ia], [io], [ie], [ea], [oa]), dan empat jenis struktur kosakata, yakni bersuku dua (VV, VKV, KVV, KVKV, VKVKV, dan KKVKV), bersuku tiga (VKVKV, KVKVKV, dan KVKKVKV), bersuku empat (KVKVKVKV, KVKVKVV, dan KVKKVKVV) dan bersuku lima (KVKVKVKVKV dan KVKVKKVKV).

Berlanjut di tahun berikutnya, yakni penelitian tentang morfologi dan sintaksis BK. Penelitian tersebut membahas tentang kata, bentukan kata, dan kalimat BK. Dari sinilah penulis memandang perlu adanya pembahasan tentang pronomina $\mathrm{BK}$, yang merupakan bagian dari unsur pengkajian morfologi, untuk ditelaah lebih lanjut dalam tulisan ini.

\section{Kerangka Teori}

Pronomina adalah segala kata yang dipakai untuk menggantikan kata benda atau kata yang dibendakan (Rohmadi, et.al, 2014: 158). Menurut Chaer (2011: 91), kata benda yang menyatakan orang sering kali diganti kedudukannya di dalam pertuturan dengan sejenis kata yang lazim disebut kata ganti.

Berdasarkan kedua definisi tersebut dapat disimpulkan bahwa pronomina atau kata ganti adalah kata yang mengacu pada nomina lain. Perhatikan contoh berikut.

(1) Andi dan Rian pergi ke Mal kemarin. Mereka membeli sepatu.

(2) Paman akan berangkat ke Ternate besok pagi. Dia akan mengikuti seminar.

Pronomina mereka dan dia pada kalimat (1) dan (2) adalah kata ganti. Kata mereka merunjuk ke Andi dan Rian pada kalimat (1) dan kata dia merujuk ke paman pada kalimat (2) yang disebutkan pada kalimat pertama.

Berdasarkan penggolongan pronomina, menurut Rohmadi, et al (2014: 158), dibedakan atas enam kelompok, yaitu pronomina persona, pronomina posesif, pronomina demonstratif, pronomina relatif, pronomina interogatif, dan pronomina intermeinatif. 


\subsection{Pronomina Persona}

Pronomina persona adalah pronomina yang digunakan untuk mengacu pada orang. Peran sintaksisnya adalah sebagai pelaku dalam kalimat. Ada tiga jenis pronomina, yaitu (1) pronomina persona pertama, yaitu kata yang menggantikan diri orang yang berbicara, (2) pronomina persona kedua, yaitu kata yang menggantikan diri orang yang diajak bicara, dan (3) pronomina persona ketiga, yaitu kata yang menggantikan diri orang yang dibicarakan. Berikut ini tabel pronomina persona dalam bahasa Indonesia.

Tabel 1

Pronomina Persona dalam Bahasa Indonesia

\begin{tabular}{|l|l|l|c|c|}
\hline \multirow{2}{*}{ Persona } & \multicolumn{3}{|c|}{ Makna } \\
\cline { 2 - 5 } & \multirow{2}{*}{ Tunggal } & \multicolumn{3}{c|}{ Eamak } \\
\cline { 3 - 5 } & \multicolumn{1}{|c|}{ Netral } & Ekslusif & Inklusif \\
\hline Pertama & saya, aku, ku-, -ku & & kami & \\
\hline Kedua & $\begin{array}{l}\text { engkau, kamu, } \\
\text { Anda, dikau, kau-, } \\
\text {-mu }\end{array}$ & $\begin{array}{l}\text { kalian, } \\
\text { kamu sekalian, } \\
\text { Anda sekalian }\end{array}$ & & \\
\hline Ketiga & ia, dia, beliau, -nya & & & \\
\hline
\end{tabular}

\subsection{Pronomina Posesif}

Pronomina posesif ialah kata yang menggantikan kata ganti orang dalam kedudukan sebagai pemilik. Dalam bahasa Indonesia dikenal tiga pronomina posesif, yakni ku, mu, dan nya, kami, kamu, dan mereka.

\subsection{Pronomina Demonstratif}

Rohmadi, et al (2014: 172) mendefinisikan pronomina demonstratif atau kata ganti penunjuk ialah segala hal yang menunjuk letak suatu benda atau yang dibendakan. Pembagian kata ganti penunjuk didasarkan pada letak atau tempat benda, yakni menunjuk letak di tempat si pembicara dengan menggunakan kata ini dan menunjuk letak di tempat lawan bicara dengan menggunakan kata itu. Hal senada juga dikatakan oleh Putrayasa (2010: 96) yang memaknai kata ganti penunjuk sebagai kata yang menunjuk tempat suatu substansi atau dapat juga mengganti substansi tersebut, yaitu kata ini dan itu.

Kata penunjuk ini dan itu memiliki lima fungsi, yakni (1) menjadi penunjuk benda, (2) menjadi penentu atau pembatas, (3) menjadi pengganti benda, (4) memberi penekanan, dan (5) menjadi penunjuk hubungan atau pertalian
(Chaer, 2014: 110). Selain fungsi yang dimiliki, dalam bahasa Indonesia, dikenal juga bentuk prononomina penunjuk tempat, yakni sini, situ, dan sana. Pronomina ini sering digunakan dengan preposisi pengacu arah $d i$, ke, dan dari sehingga konstruksi tersebut dapat mengganti pronomina persona.

\section{Metode}

Penelitian ini menggunakan pendekatan deskriptif yaitu penelitian yang dilakukan semata-mata hanya berdasarkan pada faktafakta yang ada atau fenomena yang secara empiris hidup pada penuturnya, sehingga yang dihasilkan atau yang dicatat berupa perian bahasa yang bisa dikatakan sifatnya seperti potret atau paparan seperti apa adanya (Sudaryanto, 1993: 62).

Data dalam penelitian ini adalah data primer, yakni korpus bahasa yang diperoleh dari penutur yang menetap di desa Samuya, Kecamatan Taliabu Timur, Pulau Taliabu, berupa kata-kata, ujaran-ujaran dalam bentuk cerita, dan ungkapan. Jumlah penutur yang dijadikan informan sebanyak lima orang dengan kriteria seperti yang dikemukakan oleh Mahsun (2007: 141), yakni. 
(1) Berjenis kelamin pria atau wanita;

(2) Berusia antara 25-65 tahun;

(3) Orang tua, istri atau suami informan lahir dan dibesarkan di desa itu serta jarang atau tidak pernah meninggalkan desanya;

(4) Berpendidikan maksimal tamat pendidikan dasar (SD-SMP);

(5) Berstatus sosial menengah (tidak rendah atau tidak tinggi). Dengan harapan tidak terlalu tinggi mobilitasnya;

(6) Pekerjaan bertani atau buruh;

(7) Memiliki kebanggaan terhadap isoleknya;

(8) Dapat berbahasa Indonesia.

Untuk memperoleh data tersebut, peneliti menggunakan daftar kosakata Swadesh dan kosakata budaya dasar, alat perekam suara dan video, serta pedoman wawancara sebagai instrumen. Penggumpulan data dilakukan dengan menggunakan tiga metode, yaitu metode simak (pengamatan/observasi), metode cakap (wawancara), dan metode introspeksi. Metode tersebut menggunakan teknik simak, cakap semuka, catat, rekam, dan pancing.

Analisis data menggunakan pendekatan struktural, yakni mengidentifikasi satuan-satuan dengan memperhatikan bentuk, makna, unsur, struktur, distribusi satuan-satuan itu dengan teknik bagi unsur langsung sebagai teknik dasar dan teknik lesap, teknik pindah, dan teknik sisip sebagai teknik lanjutan. Penyajian data dilakukan dengan teknik informal, yaitu data disajikan dengan menggunakan kata-kata biasa termasuk penggunaan terminologi yang bersifat teknis (Mahsun, 2014: 123).

\section{Pembahasan}

\subsection{Pronomina Persona}

Pronomina persona BK terdiri atas pronomina persona pertama tunggal aku 'aku/saya', pronomina persona pertama jamak kami 'kami' dan kito 'kita', pronomina persona kedua tunggal kou/ke 'kamu/engkau', pronomina persona ketiga tunggal io 'dia', dan pronomina persona ketiga jamak matu 'mereka'. Dalam pemakaiannya, persona pertama tunggal aku 'aku/saya' jika dikonstruksi dengan nomina dan verba, terjadi pelesapan huruf menjadi $a$ 'aku/saya'. Contoh, aloi 'kaki aku', anata 'mata saya', anaha 'rumah aku', aduka 'saya membeli', alau 'saya pergi'. Begitu pula dengan pronomina persona kedua tunggal, dalam pemakaiannya, kou 'kamu/engkau' mengacu pada orang yang sebaya, sedangkan ke 'kamu/engkau' mengacu pada orang yang lebih tua atau orang yang dituakan. Contoh pronomina persona BK tersaji dalam kalimat di bawah ini

1. aduka kalambi hino pasar 'saya membeli baju di pasar'

2. kou lau hino gina 'kamu pergi ke sawah'

3. kito dango mbape 'kita melihat gunung'

4. ke ege ndolu 'engkau mengangkat batu'

5. io mine musik 'dia mendengar musik'

6. baba duka akalambi 'ayah membelikan saya baju'

7. mina gata kito 'ibu memanggil kita'

8. uli gabu kou 'adik memeluk kamu'

9. mugufine gata io 'nenek memanggil dia'

10. kalambi yo matu na duka 'baju dibeli mereka'

Pronomina persona pada contoh di atas meliputi pronomina sebagai subjek dan pronomina sebagai objek. Pronomina sebagai subjek dalam contoh $1-5$, yakni aduka 'saya membeli', kou lau 'kamu pergi', kito dango 'kita melihat', ke ege 'engkau/kamu mengangkat', dan io mine/imine 'dia mendengar'. Pronomina sebagai objek dalam contoh 6-10, yakni a dalam kata akalambi 'saya baju', kito 'kita', kou 'kamu', io 'dia', matu 'mereka'.

\subsection{Pronomina Posesif}

Pronomina posesif ialah kata yang menggantikan kata ganti orang dalam kedudukan sebagai pemilik. Pronomina posesif selalu menyatakan kepunyaan atau pemilik. Contoh pronomina posesif $\mathrm{BK}$ tersaji di bawah ini
11. ango
'saya (milik) hidung'
'hidung saya'
12. kito naha 'kita (milik) rumah' 'rumah kita'
13. kou gina 'kamu (milik) sawah' 'sawah kamu' 
14. matu lage 'mereka (milik) perahu' 'perahu mereka'

15. io kalambi 'dia (milik) baju'

'baju dia'

Pronomina posesif pada contoh di atas merupakan pronomina posesif yang diikuti nomina, yakni ngo 'hidung', naha 'rumah', gina 'sawah', lage 'perahu', dan kalambi 'baju'.

\subsection{Pronomina Demonstratif}

Pronomina demonstratif pada BK yang menunjuk letak di tempat si pembicara, yaitu yai 'ini' dan yang menunjuk letak di tempat lawan bicara, yaitu yo 'itu'. Keduanya, yai dan yo, ditempatkan bebas setelah nomina yang diwatasinya. Contoh pronomina demonstratif BK tersaji di bawah ini
16. yai kayaka
'ini obat'
17. yai habu
18. yai ndia
'ini tikar'
19. yo mbape
'ini durian'
20. yo takalawa
'itu gunung'
'itu laba-laba'
21. yo sanga
'itu buaya'

Contoh 16-18 merupakan pemakaian pronomina demonstratif yang berfungsi untuk menunjuk benda yang dekat dari pembicara, yaitu kayaka 'obat', habu 'tikar', dan ndia 'durian'. Contoh 19-21 merupakan pemakaian pronomina demonstratif yang berfungsi untuk menunjuk benda atau hal yang jauh dari si pembicara, yaitu mbape 'gunung', takalawa 'laba-laba', dan sanga 'buaya'. Contoh-contoh tersebut dapat saja ditempatkan bebas setelah nomina yang diwatasinya, seperti yai kayaka 'ini obat' bisa ditempatkan menjadi kayaka yai 'obat ini', yo sanga 'itu buaya' bisa ditempatkan menjadi sanga yo 'buaya itu', dan seterusnya.

Pronomina demonstratif dapat pula berfungsi sebagai penentu atau pembatas benda.

Contoh tersebut tersaji di bawah ini

22. wayo yai huda usu

'air ini diambil untuk mandi'

23. kayaka yai mbarai

'obat ini pahit'

24. naha yo haya

'rumah itu besar'

25. kabi nana yo hino karunga

'anak kambing itu ada di kandang'

\subsection{Pronomina Lain}

Pronomina lain (khusus untuk hewan) dalam BK dapat dilihat pada beberapa contoh berikut ini.

$\begin{array}{lll}\text { 26. mainina yo } & \text { iti } \\ \text { 'semut' 'itu', 'kecil' } \\ \text { 'semut itu kecil', } \\ \text { 27. ule yo } & \text { nito } \\ \text { 'ular' 'itu', } & \text { 'pendek' } \\ \text { 'ular itu pendek' } & \\ \text { 28. kaminde yai } & \text { haya } \\ \text { 'tikus' 'ini' } & \text { 'besar' } \\ \text { 'tikus ini besar' } & \end{array}$

\subsection{Pronomina Interogatif}

Pronomina interogatif ialah kata-kata yang digunakan sebagai pembantu di dalam kalimat yang menyatakan pertanyaan. Pertanyaan tersebut dapat mengenai orang, benda, atau keadaan. Dalam BK, untuk menanyakan orang ialah kata woi 'siapa', untuk menanyakan benda ialah kata mansa 'apa'. Contoh pronomina interogatif tersaji di bawah ini
29. woi?
30. woi yo?
'siapa?'
31. kalambi yo woi mai?
'siapa itu?'
'baju itu untuk siapa?'
32. mina ke dendu mansa? 'ibu sedang masak

33. uli manuli mansa?

apa?

'adik sedang menulis apa?'

34. kou duka mansa?

'apa yang kamu beli?'

35. matu yo tano mansa?

'apa yang mereka tanam?'

\section{Simpulan}

BK merupakan bahasa daerah yang memiliki struktur yang sederhana. Pronomina BK umumnya terdiri atas satu dan dua suku kata, seperti aku 'aku', kami 'kami', kito 'kita', kou/ke 'kau/engkau', io 'dia', dan matu 'mereka'. Pronomina persona BK meliputi pronomina persona pertama tunggal/jamak, pronomina persona kedua tunggal/jamak, dan pronomina persona ketiga tunggal/jamak. Pronomina persona pertama BK $a k u$ 'aku' dan kami 'kami' tidak berbeda dengan pronomina persona pertama yang ada dalam bahasa Indonesia. Akan tetapi, pronomina persona 
pertama tunggal dalam pemakaiannya terjadi pelesapan menjadi $a$ 'aku'.

Pronomina demonstratif BK, yakni yai 'ini' dan yo 'itu', sedangkan pronomina introgatif, yakni woi 'siapa' yang mengacu pada orang, dan mansa 'apa' yang mengacu pada benda. Pronomina introgatif $\mathrm{BK}$ selain kedua hal tersebut, seperti kapan, bagaimana, dan mengapa masih perlu untuk dilakukan telaah lebih mendalam.

\section{Daftar Pustaka}

BPS Kabupaten Sula. 2016. Kecamatan Taliabu Timur dalam Angka 2016. BPS Kabupaten Kepulauan SULA
Chaer, Abdul. 2011. Tata Bahasa Praktis Bahasa Indonesia. Jakarta: Rineka Cipta

Mahsun. 2014. Metode Penelitian Bahasa: Edisi Revisi. Jakarta: Radja Grafindo Persada

Perda Maluku Utara. 2009. Pemeliharaan Bahasa dan Sastra Daerah. Maluku Utara

Putrayasa, Ida Bagus. 2010. Kajian Morfologi: Bentuk Derivasional dan Infleksional. Bandung: Refika Aditama

Rohmadi, et all. 2014. Morfologi: Telaah Morfem dan Kata. Surakarta: Yuma Pustaka

Sudaryanto. 2015. Metode dan Aneka Teknik Analisis Bahasa. Yogyakarta: Sanata Dharma University Press 